\title{
The determinant factors affecting auditors' ability to detect fraud: Empirical study at public accounting firms in Jakarta and Tangerang
}

\section{Gracia, Ratnawati Kurnia}

Faculty of Business, Universitas Multimedia Nusantara,

Boulevard Gading Serpong, Tangerang, Indonesia

ratnawati.kurnia@lecturer.umn.ac.id

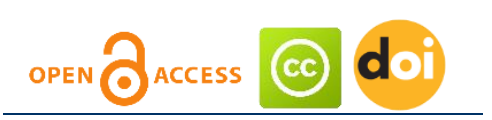

Article history:

Received: September 22, 2021

1st Revision: October 15, 2021

Accepted: November 25, 2021

\section{JEL classification: \\ H83 \\ L83}

\section{DOI:}

10.14254/jems.2021.6-2.10

\begin{abstract}
Auditor has responsibility to give audit opinion and identify whether the financial statements are free from material misstatement caused by fraud. The purpose of this research is to analyze the effect of competence, independence, time budget pressure, work experience and professional skepticism towards auditor's ability to detect fraud. The object were auditors working at Public Accounting Firms in Tangerang and Jakarta. Primary data was collected by distributing questionnaires and analyzed by using multiple linear regression. The result are competence, work experience and professional skepticism have positive significant effect towards auditor's ability to detect fraud. To increase auditor's ability in detecting fraud, auditors should improve their competence to be able to perform audit in accordance with Professional Standards for Certified Public Accountants. Public Accounting Firms must improve their auditors experience by enhancing variety of audit works and widening knowledge in various industries. Auditors must maintain their professional skepticism to provide appropriate assessment of audit evidence.
\end{abstract}

Keywords: auditor's ability to detect fraud, competence, independence, professional skepticism, time budget pressure, work experience.

\section{Introduction}

Public Accountant is one of the professions that has gained public trust, so in carrying out its duties an auditor must be responsible for maintaining the integrity and professionalism of his work. Public Accountants are trusted as independent parties who provide audit services to increase the confidence of the users of financial statements that the information in the financial statements is presented fairly and in accordance with the Statement of Financial Accounting Standards in Auditing

Corresponding author: Ratnawati Kurnia

E-mail: ratnawati.kurnia@lecturer.umn.ac.id

This open access article is distributed under a Creative Commons Attribution (CC-BY) 4.0 license. 
Standard (SA) 200 states The overall objective of the auditor is to obtain reasonable assurance whether the financial statements as a whole are free from material misstatement, caused by fraud or error(Indonesia, 2017). Material misstatements due to fraud are more difficult to identify than misstatements caused by error. This is because the fraud involved a carefully organized scheme designed to cover it up.

Although the Auditing Standards have determined that the purpose of the auditor conducting an audit is to obtain reasonable assurance that the financial statements as a whole are free from fraud, in practice there are still some cases that show the auditor's inability to detect fraud. One of them is a case related to fraud in the financial statements of a state-owned company in Indonesia. Financial statements containing such manipulation cannot be detected by the auditor so that the audit results state that the report is free from material misstatement and the opinion given is Unqualified. The Ministry of Finance disclosed negligence by auditors who had not fully complied with Auditing Standards (SA) - Professional Standards for Certified Public Accountants. For the violation, the Minister of Finance of the Republic of Indonesia imposed a sanction in the form of suspension of license for 12 months to the Public Accountant and a written warning accompanied by an obligation for the Public Accountant Firm to make improvements in the Quality Control System. The Ministry of Finance also imposed sanctions in the form of fines to all members of the Board of Directors of that state-owned company. This case shows the importance of auditors having the ability to detect fraud.

The Fraud Indonesia survey by the Association of Certified Fraud Examiners (ACFE) on 239 members of ACFE and non-members who have experience as investigators or observers of fraud in Indonesia, shows that the most common fraud in Indonesia is corruption (64.4\%), misuse of assets and company assets/wealth (28.9\%) and Financial Statement Fraud (6.7\%). In 2019, financial statement fraud resulted in a total loss of IDR $242,260,000,000$ with a case percentage of $9.2 \%$. $91.4 \%$ of respondents stated that the discovery of fraud through financial statements had an average duration of 0-12 months, and 3.2\% of respondents stated that the duration was 25-30 months. This gives an indication that the financial statement is considered very effective in minimizing the occurrence of fraud. Top 4 concealment method used by Fraudsters are: $40 \%$ created fraudulent physical documents, $36 \%$ altered physical documents, $27 \%$ altered electronic documents or files and $26 \%$ created fraudulent electronic documents or files and $12 \%$ did not involve any attempts to conceal the fraud) (Examiners, 2019)

Three main factors that contribute to fraudulent activity are depicted by the Fraud triangle: pressures, opportunities and rationalization. Undetected fraud can cause losses for many parties, both for the client company, the auditor and Public Accounting Firm. Failure to detect fraud causes the company to be subject to sanctions, including paying fines and freezing business activities. This can also lead to reduced investor confidence in the integrity of the presentation of the company's financial statements which will reduce investor interest in investing. Auditors who fail to detect fraud are also sanctioned for violating SPAP as a guideline in carrying out their profession. This can result in a decline in the reputation of the auditor and the Public Accounting Firm which will have an impact on the loss of public confidence in the credibility and independence of the public accounting profession.

Seeing the big losses that can be caused, the auditor's ability to detect fraud has an important role in every audit. The ability to detect fraud plays an important role for the auditor in understanding and assessing the client's internal control, determining the level of materiality risk, evaluating and testing audit evidence so that it can be considered by the auditor in providing an opinion on the financial statements as the final stage of the audit process. An auditor who is able to detect fraud will produce audited financial statements that are in accordance with the actual conditions of the company. The quality of financial statement information produced is reliable and trustworthy so as not to mislead users of financial statements in making economic decisions. Auditors who are able to detect fraud will also increase their professionalism and professional integrity so that they can increase trust in the eyes of the public. The ability of the auditor to detect fraud is the ability or expertise of the auditor in identifying whether there is fraud in an entity being examined. This study aims to obtain empirical evidence regarding the factors that can affect the auditor's ability to detect fraud. Whether competence, independence, work experience and professional skepticism have a positive effect towards the auditor's ability to detect fraud. And does time budget pressure negatively affect the auditor's ability to detect fraud? 


\section{Materials and method}

\subsection{Auditing}

Auditing is an examination carried out critically and systematically by an independent party on the financial statements that have been prepared by management, along with accounting records and supporting evidence with the aim of being able to provide an opinion on the fairness of the financial statements (Agoes, 2017). In Auditing Standards (SA) 200, the purpose of audit is to increase the level of confidence of the intended users of financial statements. This is achieved through the expression of an opinion by the auditor on whether the financial statements are prepared, in all material respects, in accordance with an applicable financial reporting framework (Institut Akuntan Publik Indonesia, 2017).

The audit must be carried out by a competent and independent person, namely a public accountant or auditor. Auditing Standards (SA) 700 explains that at the end of the audit process, the auditor must formulate an opinion on whether the financial statements are prepared, in all material respects, in accordance with the applicable reporting framework (Institiut Akuntan Public Indonesia, 2017). To formulate that opinion, auditor shall conclude whether the auditor has obtained reasonable assurance about whether the financial statements as a whole free from material misstatement, whether caused by fraud or error.

\subsection{Auditor's ability to detect fraud}

SA 240 defines fraud as an intentional act by one or more individuals in management, those charged with governance, employees, or third parties that involves the use of deception to gain unfair advantage or violate the law (Institut Akuntan Publik Indonesia, 2017). Fraud is categorized into three major groups:

1. Corruption: is an act of abuse of authority in business activities to gain advantage from other parties in violation of the law.

2. Misappropriation of Assets: is an act of misappropriation or theft of assets of a company or other party.

3. Financial statement fraud: is an act that is done intentionally which can cause material misstatement in the financial statements (Examiners, 2018)

The ability of the auditor to detect fraud as the auditor's skills or expertise to obtain sufficient initial indications of fraud, while at the same time narrowing the space for the perpetrators of fraud. SA 240 states that the auditor who performs an audit in accordance with the SA is responsible for obtaining reasonable assurance whether the financial statements as a whole are free from material misstatement caused by fraud or error (Institut Akuntan Publik Indonesia, 2017)

The ability of auditors to detect fraud can be measured by two indicators: knowledge about fraud and ability to detect fraud. Knowledge of fraud includes knowledge of the types of fraud, the modes and techniques used by the perpetrators of fraud, and the characteristics of fraud inherent in each fraudulent act. Ability in the detection stage includes an understanding of the client organization's internal control structure, the philosophy and operating style of employees, tracing the history of fraud, parties who can commit fraud, the factors causing fraud, identification of fraud, and communicating the results of the fraud identification and provide recommendations to the auditee (Hartan \& Waluyo, 2016)

\subsection{Competence}

Auditor competence is the professional knowledge and expertise of the auditor in completing an engagement either jointly in a team or independently based on the Professional Standards of Public Accountants (SPAP), codes of ethics and legal provisions (Institut Akuntan Publik Indonesia, 2017). Competence is measured by indicators of knowledge and experience (Pranadata, 2016). High competence is shown by the auditor in carrying out his duties having adequate knowledge of accounting standards and audit procedures in accordance with SPAP which causes the auditor to have an understanding of the company's internal control and be able to assess its effectiveness so that the auditor is able to provide an assessment of indications of fraud, types and characteristics of fraud that occurred. High competence is also indicated by the auditor being able to understand the various conditions of the client company so that the auditor can assess the risk of material misstatement and determine the nature, timing and scope of audit procedures in accordance with Professional Standards of Public Accountants (SPAP) to obtain sufficient and appropriate audit evidence so that the auditor is able to identify the risk of material misstatement due to fraud, the 
causal factors, and parties who involved in fraud so that the auditor's knowledge of fraud increases which indicates the auditor's ability to detect fraud is increasing.

Auditors who have high competence because of their expertise make it easy to recognize the symptoms of fraud that arise during the audit process. This causes the auditor to quickly and accurately detect any acts of fraud as well as engineering tricks carried out in the fraud (Said \& Munandar, 2018). This is in line with previous studies show that competence has a positive effect on the auditor's ability to detect fraud (Hartan \& Waluyo, 2016), (Peuranda et al., 2019). However other studies stated that competence has no effect on the auditor's ability to detect fraud (Agustin, 2019). Based on the description, the hypothesis is

Ha1 : Competence has a positive effect on the auditor's ability to detect fraud.

\subsection{Independence}

In the Code of Ethics for the Professional Public Accountant, independence is the attitude of the auditor who maintains objectivity, integrity, professionalism and ethics by staying away from conditions that can doubt the integrity and objectivity of third parties during the audit engagement (Institut Akuntan Publik Indonesia, 2017). Independence can be measured by three indicators: the independence in preparing audit programs, independence of audit work implementation and independence of reporting. Emphasis is placed on the attitude of independence to maintain the level of professionalism of the auditor in carrying out the audit (Tuanakotta, 2015)

Auditors who have high independence in preparing the audit program will be free from interference from any party to modify or determine the selected procedures that cause the auditor to design and perform audit procedures in accordance with SPAP and conduct tests on the effectiveness of the client's internal control and assess the risks appropriately so that the auditor is able to provide an assessment related to indications of fraud in the company. High independence also makes the auditor free from the interests of other parties that can limit the audit process so that the auditor is able to carry out audit procedures in accordance with SPAP, freely access the required documents and perform tests on the accuracy of transactions adequately to obtain sufficient audit evidence so the auditor is able to provide an assessment and identify whether there is a material misstatement due to fraud. High independence also causes the auditor to be free from pressure from any party in disclosing audit facts and findings during the audit process so the auditor can communicate audit results that are in accordance with the company's conditions and identify indications of fraud within the company so that the auditor's knowledge of fraud increases which indicates the ability of auditors to detect fraud is increasing

Auditors who have independence when detecting fraud are able to report fraudulent actions even though they are under pressure from other parties. Previous studies state that independence has a positive influence on the ability of auditors to detect fraud (Indrawati et al., 2019)(Sofie \& Nugroho, 2019). However, the other studies show that independence has no effect on the ability of auditors to detect fraud (Larasati \& Puspitasari, 2019). Based on the description the hypothesis is

Ha2.: Independence has a positive effect on the auditor's ability to detect fraud

\subsection{Time budget pressure}

Time budget pressure is a condition in which the auditor is required to make efficient use of the time available to complete the audit assignment according to the time specified (Said \& Munandar, 2018). Time budget pressure is measured by indicators of time budget planning and audit time effectiveness (Rosadi \& Waluyo, 2017). Time budget planning provides a basis for estimating audit costs, allocation of audit staff and as a basis for evaluating the performance of the auditors to what extent the work is carried out in accordance with established time budget procedures and requirements (Julianto et al., 2016)

The low time budget pressure causes the auditor to have sufficient time in planning the audit program and evaluating the client company's internal control structure and assessing its effectiveness so that the auditor is able to provide an indication of the presence or absence of fraud, the type and characteristics of the fraud that occurred. Low time budget pressure is also indicated by the availability of sufficient time for auditors to carry out audit procedures according to SPAP by conducting substantive tests to assess the accuracy of transactions so that the auditor can obtain sufficient and appropriate audit evidence that can support the auditor in providing an assessment and identifying whether there is material misstatement due to fraud, the type of fraud that occurred and the factors causing it so that knowledge auditors regarding fraud is increasing which shows the auditor's ability to detect fraud is increasing 
Time-stressed conditions will cause auditors to tend to behave dysfunctional, such as prematurely signing off, trusting too much in client explanations and presentations, and failing to investigate relevant issues, which ultimately results in auditors failing to detect fraud in reports. company finances (Fadhilah, 2018). Previous studies showed that time budget pressure has a negative effect on the auditor's ability to detect fraud (Fadhilah, 2018), (Idawati, 2019),(Arsendy, 2017). However, the other studies state that time budget pressure has no effect on the auditor's ability to detect fraud (Rosiana et al., 2019), (Purba \& Nuryatno, 2019). Based on the description the hypothesis is

На3 : Time budget pressure has a negative effect on the auditor's ability to detect fraud

\subsection{Work experience}

Work experience is the experience the auditor has in auditing financial statements, both in terms of the length of time and the number of assignments that have been handled (Arsendy, 2017). High work experience is marked by the longer a person works as an auditor and the more audit assignments are handled, which causes the auditor to be more capable of dealing with the object of examination in obtaining the information needed to properly assess the client's internal control risk and provide an indication of the presence or absence of fraud, the type and characteristics of the fraud that occurred. High work experience also makes auditors more careful and thorough in completing their duties and have the opportunity to learn from the failures and successes experienced so that in the process of collecting audit evidence, the accuracy and adequacy of the evidence can be achieved and the auditor is able to test the evidence obtained appropriately and can identify whether there are indications of material misstatement due to fraud, the type of fraud that occurs, and the factors causing it so that the auditor's knowledge of fraud increases which indicates the auditor's ability to detect fraud is increasing.

Auditors who have a lot of experience will not only have the ability to find errors or unreasonable fraud contained in financial statements but also auditors can provide a more accurate explanation of the findings obtained compared to auditors who are still have little experience (Sukendra et al., 2015). Experienced auditors have more knowledge about errors and fraud which causes auditors to produce better performance in detecting cases of fraud compared to inexperienced auditors (Sari \& Helmayunita, 2018). Previous studies states that work experience has a positive effect on the auditor's ability to detect fraud (Rosiana et al., 2019) (Laitupa, 2020) (Suryanto et al., 2017)(Ranu \& Merawati, 2017). Based on the description the hypothesis is

$\mathrm{Ha}_{4}$ : Work experience has a positive effect on the auditor's ability to detect fraud.

\subsection{Professional skepticism}

SA 200 states that professional skepticism is an attitude that includes a questioning mind, being alert to conditions that may indicate possible misstatements, whether caused by fraud or error, and an important assessment of audit evidence. The auditor must plan and carry out the audit with professional skepticism considering that certain conditions may occur that cause the financial statements to be materially misstated. Professional skepticism as a questioning attitude, alertness to circumstances that indicate a possible misstatement due to error or fraud and a critical assessment of the evidence ( Institut Akuntan Publik Indonesia, 2017). With high professional skepticism, the auditor will be more vigilant and diligent in obtaining sufficient and adequate audit evidence and critically evaluate any evidence obtained so that the auditor is able to provide appropriate assessments regarding the effectiveness of internal control and identify indications regarding the presence or absence of fraud, the types and characteristics of fraud that occurred. High professional skepticism also causes auditors to be able to question audit evidence whose validity is dubious and request additional evidence from clients if the evidence obtained is not sufficient so that the auditor is able to obtain the adequacy and accuracy of audit evidence to assess and identify whether there are indications of material misstatement due to fraud, factors causing fraud, or parties who can commit fraud so that the auditor's knowledge of fraud increases which indicates the ability of auditors to detect fraud is increasing.

Skeptic auditors will assume that the best internal control system still has gaps that allow fraud to occur (Indrawati et al., 2019). Auditors who have a high level of skepticism have a thorough nature and always seek the truth of the evidence they receive so that it will be easier to detect fraud (Indriyani \& Hakim, 2021). Previous study states that professional skepticism has a positive effect on the ability of auditors to detect fraud (Indrawati et al., 2019)(Sofie \& Nugroho, 2019)(Idawati, 2019). However, the other study state that professional skepticism has no effect on the ability of auditors to detect fraud (Ranu \& Merawati, 2017). Based on the description the hypothesis is 
$\mathrm{Ha}_{5}$ : Professional skepticism has a positive effect on the ability of auditors to detect fraud.

Figure 1: Research framework

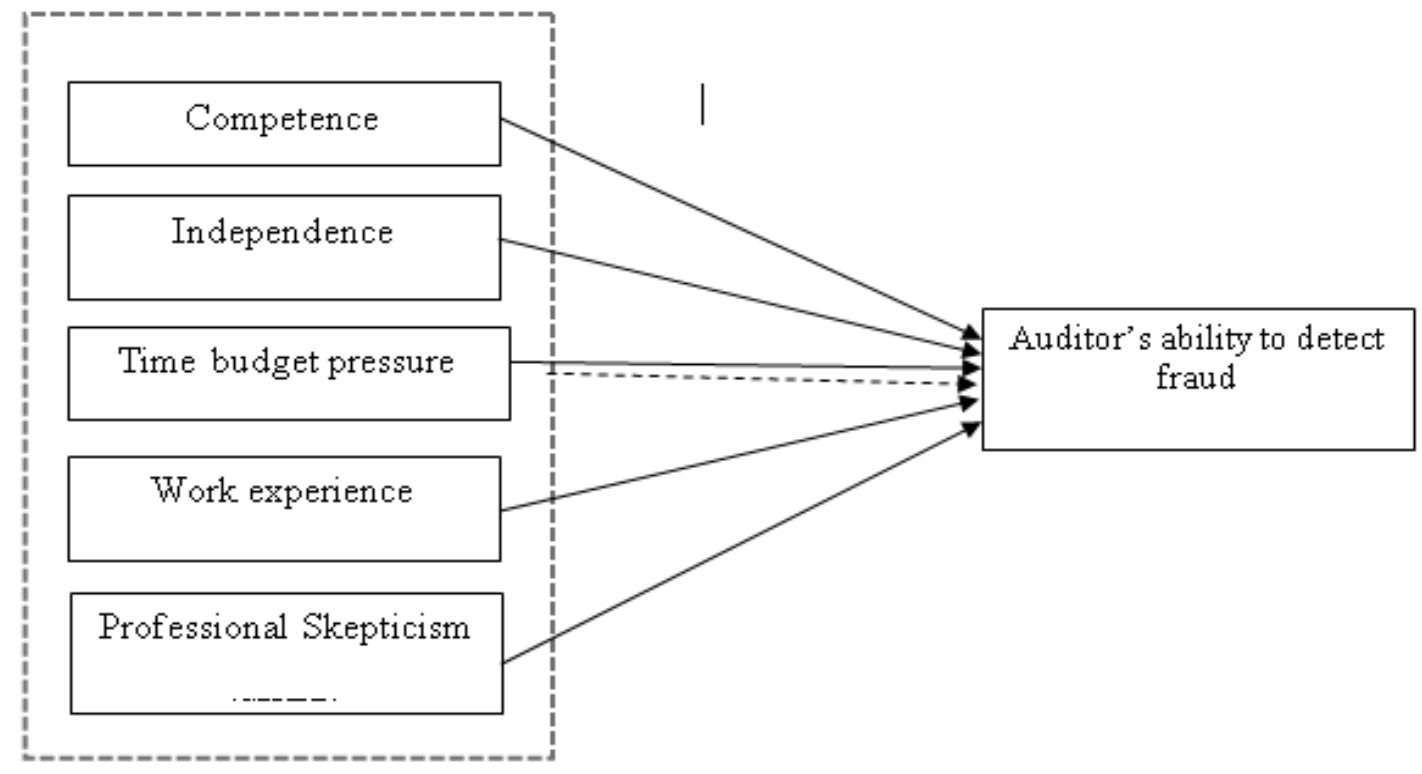

\subsection{Methods}

The respondents in this study are auditors who work in Public Accounting Firms in Tangerang and Jakarta with a minimum position of senior auditor and a minimum educational background of Bachelor Degree of Accountancy. The data obtained in this study are primary data using the convenience sampling method by distributing online questionnaires. All variables in this study were measured using an interval scale using a Likert scale by scoring as follows (1) Strongly Disagree, (2) Disagree, (3) Neutral, (4) Agree, and (5) Strongly Agree.

The dependent variable in this study is the auditor's ability to detect fraud, that is the knowledge possessed by the auditor to identify fraud and the auditor's ability to detect indications of fraud in the audit assignment. This variable is measured by 2 indicators, namely knowledge about fraud and ability in the detection stage. This variable is operationalized by using 9 positive statements and 1 negative statement contained in number 6 (Hartan \& Waluyo, 2016).

\subsection{Variables}

There are 5 variables involved in this research framework:

\subsubsection{Competence}

Competence is the professional expertise and experience possessed by the auditor in applying knowledge to complete an audit engagement based on the Professional Standards of Public Accountants and the code of ethics of public accountants. Competence in this study was measured using 2 indicators : the knowledge and experience of the auditor. This variable is operationalized by using 9 positive statements with 1 negative question contained in number 9 (Dahlia \& Octavianty, 2016).

\subsubsection{Independence}

Independence is the attitude of the auditor who maintains objectivity, integrity, and professionalism impartially and is free from the influence of certain parties including management and other parties in preparing audit programs, conducting audit examinations, and reporting audit results. The indicators used to measure this variable are the independence of the preparation of the audit program, the independence of the implementation of the work, and the independence of reporting. This variable is operationalized by using 9 positive statements. 


\subsubsection{Time budget pressure}

Time budget pressure is a condition that requires the auditor to plan a time budget and perform auditing activities efficiency in order to carry out audit procedures according to the planned time. This variable is measured by indicators of time budget planning and audit time effectiveness. This variable is operationalized by using 5 positive statements (Rosadi \& Waluyo, 2017).

\subsubsection{Work experience}

Work experience is a measure of the time or tenure of the auditor and the number of audit examination tasks that have been handled which can improve the performance of the auditor. With the increasing number of audit examination tasks, the auditor has experience in carrying out audit procedures so that they increasingly understand the information needed to be able to conduct audits more quickly. Indicators to measure this variable are the length of work as an auditor and the number of inspection tasks. This variable is operationalized by using 8 positive statements.

\subsubsection{Professional skepticism}

Professional skepticism is the attitude of the auditor who is always questioning, alert, not easy to believe and makes a critical assessment of audit evidence in order to obtain sufficient and appropriate audit evidence. The indicator to measure this variable is awareness of audit evidence. This variable is operationalized by using 6 positive statements (Sukendra et al., 2015).

\subsection{Hypothesis test}

The multiple linear regression formula used in this study is as follows

$$
\begin{aligned}
& K M K=\alpha+\beta_{1} K O M+\beta_{2} I N D-\beta_{3} T A W+\beta_{4} P K+\beta_{5} S P+e \\
& \text { where KMK - Auditor 's Ability to Detect Fraud } \\
& \alpha \text { - Constant } \\
& \beta_{1}, \beta_{2}, \beta_{3}, \beta_{4}, \beta_{5} \text { - Regression coefficient } \\
& \text { KOM - Competence } \\
& \text { IND - Independence } \\
& \text { TAW - Time Budget Pressure } \\
& \text { PK - Work Experience } \\
& \text { SP - Professional Skepticism }
\end{aligned}
$$

\section{Results}

The number of questionnaires distributed was 741 questionnaires, distributed to 24 Public Accounting Firms in Jakarta and Tangerang from March 3, 2021 up to April 4, 2021. The number of returned questionnaires is $127(17,14 \%)$ and 125 questionnaires $(16,87 \%)$ can be used in this study. The low response rate was due to pandemic situation in Jakarta and Tangerang. From the results of the validity test, all variables used in this study had a sig (2-tailed) of $0.000 \mathrm{or}<0.05$. This shows that all statements in the study have been declared valid. Based on the results of the reliability test, the results of Cronbach's Alpha Based on Standardized Items for all variables used above 0.7, it can be concluded that all variables are declared reliable. All variables in the regression model are normally distributed. There is no multicollinearity among the independent variables and there is no heteroscedasticity in the regression model

\section{Table 1: Results of the coefficient of determination test}

\section{Model Summary}

\begin{tabular}{ll|r|r|r} 
Model & R & R Square & \multicolumn{1}{c}{$\begin{array}{c}\text { Adjusted R } \\
\text { Square }\end{array}$} & $\begin{array}{c}\text { Std. Error of } \\
\text { the Estimate }\end{array}$ \\
\hline 1 & $.663^{a}$ & .439 & .416 & 3.146 \\
\hline
\end{tabular}

a. Predictors: (Constant), SP, TAW, KOM, IND, PK

b. Dependent Variable: KMK 
Based on the results of the coefficient of determination test, the $\mathrm{R}$ value of 0.663 indicates that there is a correlation with a strong category between the dependent variable and the independent variable. The value of Adjusted $\mathrm{R}^{2}$ is 0.416 , indicating that the auditor's ability to detect fraud can be explained by the five independent variables of $41.6 \%$. Meanwhile, the remaining $58.4 \%$ is explained by other variables outside the research model such as professional ethics, work load and due professional care

\begin{tabular}{|c|c|c|c|c|c|c|}
\hline \multicolumn{7}{|c|}{ ANOVA $^{a}$} \\
\hline Model & & $\begin{array}{l}\text { Sum of } \\
\text { Squares }\end{array}$ & df & Mean Square & $\mathrm{F}$ & Sig. \\
\hline \multirow[t]{3}{*}{1} & Regression & 922.958 & 5 & 184.592 & 18.653 & $.000^{\mathrm{b}}$ \\
\hline & Residual & 1177.634 & 119 & 9.896 & & \\
\hline & Total & 2100.592 & 124 & & & \\
\hline
\end{tabular}

The $\mathrm{F}$ table value is 2.29 which is obtained from the $\mathrm{F}$ distribution table at a significance level of 0.05 with degrees of freedom 119. Therefore, the calculated $F$ value is greater than the $F$ table value $(18.653>2.29)$ which indicates that the Competence, Independence, Time budget pressure, Work experience, and Professional skepticism simultaneously affect the auditor's ability to detect fraud. A significance level of $0.000(<0.05)$ was obtained which indicates the F statistical test has met the goodness of fit criteria, which means the model can be used to predict the auditor's ability to detect fraud.

Table 3: T-statistical test result

\begin{tabular}{|c|c|c|c|c|c|c|}
\hline \multirow[b]{3}{*}{ Model } & & \multicolumn{5}{|c|}{ Coefficients $^{a}$} \\
\hline & & \multicolumn{2}{|c|}{ Unstandardized Coefficients } & \multirow{2}{*}{$\begin{array}{c}\text { Standardized } \\
\text { Coefficients } \\
\text { Beta }\end{array}$} & \multirow[b]{2}{*}{$\mathrm{t}$} & \multirow[b]{2}{*}{ Sig. } \\
\hline & & $\mathrm{B}$ & Std. Error & & & \\
\hline \multirow[t]{6}{*}{1} & (Constant) & 3.811 & 3.988 & & .956 & .341 \\
\hline & KOM & .281 & .086 & .272 & 3.273 & .001 \\
\hline & TAW & .094 & .088 & .075 & 1.066 & .289 \\
\hline & IND & .101 & .081 & .111 & 1.240 & .217 \\
\hline & PK & .271 & .117 & .217 & 2.312 & .022 \\
\hline & $\mathrm{SP}$ & .376 & .158 & .225 & 2.378 & .019 \\
\hline
\end{tabular}

a. Dependent Variable: KMK

$K M K=3,811+0,281 K O M+0,101 I N D+0,094 T A W+0,271 P K+0,376 S P$

\section{Discussion}

$\mathrm{Ha}_{1}$ : Competence has a positive effect on the auditor's ability to detect fraud $\boldsymbol{A C C E P T E D}$

Based on the results of the t-statistical test. The competency variable has a sig value of 0.001 $(<0.05)$ states that competence has a significant positive effect on auditor's ability to detect fraud. The results of this study are in line with previous studies state that competence has a positive effect on the ability of auditors to detect fraud (Hartan \& Waluyo, 2016); (Said \& Munandar, 2018) (Peuranda et al., 2019).

Ha2.: Independence has a positive effect on the auditor's ability to detect fraud $\boldsymbol{R E J E C T E D}$

The independence variable has a regression coefficient of 0.101 with a positive direction. The independence variable sig value $0.217(>0.05)$ states that independence does not have a positive significant effect on the auditor's ability to detect fraud. $51.20 \%$ or 64 respondents have an average answer of independence below the average 4.36, but among 64 respondents there are $34.38 \%$ of respondents who have an average answer to the statement of the auditor's ability to detect fraud above the average 4.08. Thus, even though there are respondents with below-average independence, respondents have high ability to detect fraud. This is because in carrying out audit assignments, the auditor is still guided by the SPAP and Code of Ethics for the Professional Public Accountant so that the auditor continues to carry out all audit procedures according to SPAP and obtain sufficient and 
appropriate audit evidence that can be used as a basis for assessing in detecting the presence or absence of fraud. and produce audit results that match the actual company conditions

Independence has no significant effect on the auditor's ability to detect fraud because the majority of respondents in this study are senior auditors, amounting to $82.40 \%$ or 103 respondents. In conducting the audit, the senior auditor is more involved in the implementation of the audit examination and follows the audit program that has been determined. The senior level of auditors has also not been involved in making professional judgments and decisions related to the reporting of audit results so that the majority of respondents have not been able to be involved in planning audit procedures and drawing conclusions on audit results. Therefore, independence has no effect on the auditor's ability to detect fraud. The results of this study are consistent with previous studies which show that independence does not affect the auditor's ability to detect fraud (Larasati \& Puspitasari, 2019), (Indrasti \& Sari, 2019). However, this is not in line with the results of previous studies which state that independence has a positive effect on the ability of auditors to detect fraud (Indrawati et al., 2019), (Sofie \& Nugroho, 2018)

$\mathrm{Ha}_{3}$ : Time budget pressure has a negative effect on auditor's ability to detect fraud $\boldsymbol{R E J E C T E D}$

The time budget pressure variable has a regression coefficient of 0.094 with a positive direction. This shows that the existing time budget pressure is increasing, the auditor will make time budget planning and make auditing activities efficient by doing overtime, continuing to work on holidays, or utilizing technology that can support the implementation of all audit procedures needed to obtain sufficient and appropriate audit evidence that will be the basis of the assessment in detecting the presence or absence of fraud according to the planned time.

The time budget pressure has a significance value of 0.289 (greater than 0.05 ) w states that time budget pressure has no negative significant effect on the auditor's ability to detect fraud. Timeliness in completing an audit engagement is one of the important indicators underlying the auditor's performance assessment. Even though the auditor is experiencing time budget pressure, the auditor will make efficient use of the available time and carry out audits according to SPAP to obtain sufficient and appropriate audit evidence that will be used to detect fraudulent acts so that the audit results will be in accordance with the actual company conditions and the audit can be completed according to the planned time so that it will improve the assessment of the auditor's performance

Respondents in this study were dominated by senior auditors, as many as $82.40 \%$ or 103 respondents. In carrying out the audit, the party who is responsible for planning and coordinating the audit time so that it fits the schedule set is the audit manager. Therefore, the majority of respondents do not have access to plan or change the audit time budget so that in carrying out their duties, the majority of respondents can only follow the directions given by the manager. As written in the Financial Services Authority Regulation No. 44 of 2016 regarding the audit deadline which states that the audited annual financial statements must be submitted to the 0JK no later than 90 days after the end of the financial year. This shows that the auditor must continue to audit according to SPAP and produce quality audits and according to the actual conditions of the company according to the time limit. Thus, time budget pressure has no effect on the auditor's ability to detect fraud. The results of this study are consistent with the results of research which state that time budget pressure does not affect the ability of auditors to detect fraud (Rosiana et al., 2019),(Purba \& Nuryatno, 2019). However, this is not in line with other previous results which state that time budget pressure has a negative effect on the ability of auditors to detect fraud (Fadhilah, 2018), (Idawati, 2019), (Arsendy, 2017)

$\mathrm{Ha}_{4}$ : Work experience has a positive effect on the auditor's ability to detect fraud ACCEPTED

The work experience variable has a sig value of $0.022(<0.05)$ states that work experience has a significant positive significant effect on the auditor's ability to detect fraud. The results of this study are in line with the previous studies state that work experience has a positive effect on the auditor's ability to detect fraud (Rosiana et al., 2019), (Laitupa, 2020), (Suryanto et al., 2017), (Ranu \& Merawati, 2017)

\section{ACCEPTED}

$\mathrm{Ha}_{5}$ : Professional skepticism has a positive effect on the ability of auditors to detect fraud

The professional skepticism variable has a sig value of $0.019<0.05$ ) which states that professional skepticism has a positive significant effect on the auditor's ability to detect fraud. The results of this study are in line with the previous studies state that professional skepticism has a 
positive effect on auditor's ability to detect fraud (Indrawati et al., 2019), (Sofie \& Nugroho, 2019), (Idawati, 2019)

\section{Conclusions}

The conclusion of this study is competence, work experience and professional skepticism have a positive significant effect on the auditor's ability to detect fraud. Meanwhile, time budget pressure and independence have no negative significant effect on the auditor's ability to detect fraud. In order to improve the ability to detect fraud, auditors must always maintain and improve their competence by participating in various certifications, training, and Continuing Professional Education (PPL) recommended by IAPI on a regular basis. KAP can also organize internal trainings that can equip auditors with the knowledge and expertise to carry out audits in accordance with SPAP and the Code of Ethics for the Professional Public Accountant.

KAP also needs to improve its auditor's experience in the field of auditing by increasing assignments and broadening understanding of various types of client industries. Equipped with experience in handling various assignments, the auditor will be more capable of carrying out audits and obtaining sufficient and appropriate audit evidence to assess whether there are indications of fraud that occur, thereby increasing the auditor's ability to detect fraud. During the audit engagement, the auditor must also always maintain and improve the attitude of professional skepticism by always questioning and being critical in assessing audit evidence. The attitude of professional skepticism encourages the auditor to evaluate each audit evidence in depth and understand the interrelationships between the evidence obtained so that the auditor is able to properly assess whether there are indications of fraud that occur so as to increase the auditor's ability in detecting fraud to produce high quality audit reports.

This study has limitations, that is the distribution of questionnaires is carried out in a limited scope, only to KAP in the Tangerang and Jakarta areas so it cannot be generalized to all auditors in Indonesia, so it is recommended to expand the scope of the sample and find out other factors that can affect the auditor's ability to detect fraud such as professional ethics, workload, and due professional care.

\section{Acknowledgments}

This research was supported by Universitas Multimedia Nusantara (Indonesia) We thank Dr Ir. PM Winarno and our colleagues from Universitas Multimedia Nusantara (Indonesia) who supported us and offered deep insight into the study. We thank Dr Antonius Siahaan from Swiss German University (Indonesia) who provided insight and expertise. Their contributions are sincerely appreciated and grateful acknowledged.

\section{Funding}

The author(s) received no financial support for the research, authorship, and/or publication of this article.

\section{Declaration of conflicting interests}

The author(s) declared no potential conflicts of interest with respect to the research, authorship, and/or publication of this article.

\section{Citation information}

Gracia, \& Kurnia, R. (2021). The determinant factors affecting auditors' ability to detect fraud: Empirical study at public accounting firms in Jakarta and Tangerang. Economics, Management and Sustainability, 6(2), 132-145. doi:10.14254/jems.2021.6-2.10. 


\section{Reference}

Agoes, S. (2017). Auditing: Petunjuk Praktis Pemeriksaan Akuntan Oleh Akuntan Publik (Edisi 5). Jakarta: Salemba Empat.

Agustin, L. W. D. (2019). The influence of professional skepticism, independency, competence, and personality type of auditors on their ability to detect fraud. Jurnal Ilmiah Mahasiswa FEB, 7(2).

Arsendy, M.T. (2017). Pengaruh Pengalaman Audit, Skeptisisme Profesional, Red Flags, dan Tekanan Anggaran Waktu Terhadap Kemampuan Auditor Mendeteksi Kecurangan. JOM Fekon, 4(1).

Dahlia, L., \& Octavianty, E. (2016). Pengaruh Kompetensi, Independensi, dan Profesional Auditor Terhadap Kualitas Audit. Jurnal Ilmiah Akuntansi, 2(1).

Dorris, B. (2018). Report to the nations, 2018 Global study on occupational fraud and abuse. New York, Association of Certified Fraud Examiners.

Examiners, Association of Certified Fraud (2019). Survei Fraud Indonesia. ACFE Indonesia.

Fadhilah, H. (2018). The influence of professional skepticism and time budget pressure of auditor's ability to detect fraudulent financial reporting (survey on senior auditor in big four firms). International Journal of Business, Economics and Law, 16(1), 53-58.

Hartan, T.H., \& Waluyo, I. (2016). Hartan, T. H., \& Waluyo, I. (2016). Pengaruh Skeptisme Profesional, Independensi dan Kompetensi terhadap Kemampuan Auditor Mendeteksi Kecurangan (Studi Empiris pada Inspektorat Daerah Istimewa Yogyakarta). Jurnal Profita: Kajian Ilmu Akuntansi, 4(3).

Idawati, W. (2018). The auditor's ability to detect fraud: gender, professional skepticism, and time budget pressure. Avances in Economics, Business and Management Rersearch, 73, 14-16.

Indrasti, W., \& Karlina, B. (2019). Determinants affecting the auditor's ability of fraud detection: internal and external factors. Annual International Conference on Accounting Research (AICAR).

Indrawati, L., Cahyono, D., \& Maharani, A. (2019). Pengaruh Skeptisisme Profesional, Independensi Auditor dan Pelatihan Audit Kecurangan Terhadap Kemampuan Auditor dalam Mendeteksi Kecurangan. International Journal of Social Science and Business, 3(4).

Indriyani, S., \& Hakim, L. (2021). Pengaruh Pengalaman Audit, Skeptisme Profesional Dan Time Pressure Terhadap Kemampuan Auditor Mendeteksi Fraud.Jurnal Akuntansi dan Governance, 1(2), 113-120.

Institut Akuntan Publik Indonesia. (2017). Standar Profesional Akuntan Publik (SPAP). Jakarta: Salemba Empat.

Julianto, I. K. A., Yadnyana, I. K., \& Suputra, I. D. G. D. (2016). Pengaruh Audit Fee, Perencanaan Audit, dan Risiko Audit Terhadap Kualitas Audit Pada Kantor Akuntan Publik Di Bali. E-Jurnal Ekonomi Dan Bisnis Universitas Udayana, 5(1), 4029-4056.

Laitupa, M. F., \& Hehanussa, H. (2020). Pengaruh Pengalaman Kerja, Skeptisme Profesional Dan Tekanan Waktu Terhadap Kemampuan Auditor Dalam Mendeteksi Kecurangan.Jurnal Akuntansi, 6(1), 1-22.

Larasati, D., \& Puspitasari, W. (2019). Pengaruh Pengalaman, Independensi, Skeptisisme Profesional, Penerapan Etika, dan Beban Kerja Terhadap Kemampuan Auditor Dalam Mendeteksi Kecurangan. Jurnal Akuntansi Trisakti, 6(1).

Peuranda, J. H., Hasan, A., \& Silfi, A. (2019). Pengaruh Independensi, Kompetensi dan Skeptisme Profesional terhadap Kemampuan Auditor dalam Mendeteksi Kecurangan dengan Pelatihan Audit Kecurangan sebagai Variabel Moderasi. Jurnal Ekonomi, 27(1), 1-13.

Purba, S. F., \& Nuryatno, M. (2019). Kecerdasan Emosional Sebagai Pemoderasi Pengaruh Skeptisme Profesional, Independensi, Time Pressure, Locus Of Control Terhadap Kemampuan Auditor Dalam Mendeteksi Kecurangan. Jurnal Akuntansi Trisakti, 6(2), 325-344.

Ranu, G. A. Y. N., \& Merawati, L. K. (2017). Kemampuan Mendeteksi Fraud Berdasarkan Skeptisme Profesional, Beban Kerja, Pengalaman Audit dan Tipe Kepribadian Auditor. Jurnal Riset Akuntansi (JUARA), 7(1). 
Rosadi, R. A., \& Waluyo, I. (2017). Pengaruh Gender, Tekanan Ketaatan, Tekanan Anggaran Waktu dan Pengalaman Audit terhadap Audit Judgment. Nominal: Barometer Riset Akuntansi dan Manajemen, 6(1), 124-135.

Rosiana, P., Putra, I. M., \& Setiawan, Y. A. (2019). Pengaruh kompetensi auditor independen dan tekanan anggaran waktu terhadap pendeteksian fraud.Jurnal Manajemen Strategi dan Aplikasi Bisnis, 2(1), 45-52.

Said, L. L., \& Munandar, A. (2018). The Influence of Auditor's Professional Skepticism and Competence on Fraud Detection: The Role of Time Budget Pressure. Jurnal Akuntansi dan Keuangan Indonesia, 15(1), 104-120.

Sari, Y. E., \& Helmayunita, N. (2018). Pengaruh Beban Kerja, Pengalaman, dan Skeptisme Profesional Terhadap Kemampuan Auditor Dalam Mendeteksi Kecurangan (Studi Empiris pada BPK RI Perwakilan Propinsi Sumatera Barat). Wahana Riset Akuntansi, 6(1), 1173-1192.

Sofie, \& Nugroho, N. A. (2018). Pengaruh Skeptisme Profesional, Independensi, dan Tekanan Waktu Terhadap Kemampuan Auditor Mendeteksi Kecurangan. Jurnal Akuntansi Trisakti, 5(1).

Solvabilitas, U. P., Keuangan, P. K. P. L., Auditor, K. P., Audit, D. S. P. P. K., Strength, F. F. Y. M. F., Delay, P. K. T. A., ... \& Di, B. (2016). Voluntary Disclosure sebagai Pemoderasi Pengaruh Good Corporate Governance terhadap Nilai Perusahaan. E-Jurnal Akuntansi, 17(3).

Sukendra, I. P., Yuniarta, G. A., AK, S., Atmadja, A. T., \& SE, A. (2015). Pengaruh Skeptisme Profesional, Pengalaman Auditor, Dan Keahlian Audit Terhadap Ketepatan Pemberian Opini Oleh Auditor (Studi Empiris pada Inspektorat Kabupaten Buleleng, Kabupaten Bangli dan Kabupaten Karangasem). JIMAT (Jurnal Ilmiah Mahasiswa Akuntansi) Undiksha, 3(1).

Suryanto, R., Indriyani, Y., \& Sofyani, H. (2017). Determinan Kemampuan Auditor dalam Mendeteksi Kecurangan. Journal of Accounting and Investment, 18(1).

Tuanakotta, T.M. (2015). Audit Kontemporer. Jakarta: Salemba Empat. 


\section{Appendix}

\section{Questionnaires}

1. Strongly disagree. 2. Disagree, 3. Neutral, 4. Agree, 5. Strongly agree

II. COMPETENCE

1. Every public accountant must understand and perform his professional services in accordance with the relevant Financial Accounting Standards (SAK) and Public Accountants Professional Standards (SPAP)

2. To do a good audit, I need to understand the type of client industry.

3. To do a good audit, I need to understand the condition of the client's company

4. To do a good audit, I need the knowledge gained from the formal education

5. Besides the formal education, in order to do a good audit, I also need the knowledge from courses and training, especially in the field of audit

6. The special skills that I have can support the audit process that I do

7. The more clients I audit, the better the audit I do

8. I have had a lot of experience in the field of auditing with various clients so that the audits I do are getting better

9. Even though I now have a large number of clients, the audit I do is not necessarily better than before

10. I have audited go public companies, so I can do the audit for non go public companies better

Sources: Tjun, Marpaung and Setiawan (2012)

\section{TIME BUDGET PRESSURE}

1. I feel that the planning of time budget is too tight, so I don't test many transactions

2. I will carry out the audit according to the planned time even though I feel unable.

3. I will do the audit according to the planned audit time so that the audit I do is judged good by my superiors

4. I often change the audit time that has been planned in advance so that all audit procedures can be carried out

5. Time budget pressure causes a decrease in the effectiveness and efficiency of auditing activities

Sources: Rosadi (2017)

\section{INDEPENDENCE}

A. Indicators: Independence in Preparation of the Audit Program

1. The preparation of the audit program is free from the intervention of the management to determine, eliminate or modify certain parts being examined

2. The preparation of the audit program is free from management intervention regarding the audit procedures chosen by the auditor

3. The preparation of the audit program is free from the efforts of other parties to determine the subject of the audit work

B. Indicators: Independence of Audit Field Work

4. Examination is free from managerial efforts to determine or appoint the activities being examined

5. The implementation of the examination must cooperate with the managerial in providing the documents needed during the examination process

6. Examination is free from personal interest or other parties to limit all inspection activities

C. Indicators : Independence in Audit Reporting

7. Reporting is free from the obligation of other parties to influence the facts reported

8. Reporting on audit results is free from language or terms that give rise to multiple interpretations

9. Reporting is free from the efforts of certain parties to influence the examiner's consideration of the contents of the audit report

Sources: Oklivia dan Marlinah (2014) dalam Putri (2017)

\section{WORK EXPERIENCE}

A. Indicators: Length of Work as Auditor

1. The longer you are as an auditor, the more you understand how to deal with the audit entity/object in obtaining the required data and information

2. The longer you work as an auditor, the more you can find out relevant information to make judgment in decision making

3. The longer you work as an auditor, the more you can detect errors made by the object of examination

4. The longer the auditor is, the easier to find the cause of the error and can provide recommendations to eliminate/minimize the cause

B. Indicators: Number of Examination Tasks

5. The number of examination tasks requires accuracy and precision in completing them

6. Mistakes in the collection and selection of audit evidence and information can hinder the process of completing the audit field work

7. The many tasks received can give opportunity to learn from the failures and successes that have been experienced 
8. The many tasks received can trigger the auditor to complete the work quickly without the accumulation of tasks

Sources: Oklivia dan Marlinah (2014) dalam Putri (2017)

\section{PROFESSIONAL SKEPTICISM}

1. I am diligent and careful in conducting audits

2. I do not simply believe the audit evidence provided by the auditee

3. I question the audit evidence whose validity is doubtful

4. I evaluated the audit evidence

5. I gathered sufficient audit evidence and details

6. I asked for additional evidence to the auditee when I felt the evidence I got was not convincing enough

Sources: Adrian (2013) dalam Sukendra (2015)

\section{VII. $\quad$ AUDITOR'S ABILITY TO DETECT FRAUD}

A. Indicators: Knowledge About Fraud

1. I have sufficient knowledge about the types of fraud, especially those that often occur during audit assignments

2. As an auditor, I am able to assess the modes and techniques commonly used by perpetrators of fraud

3. I understand the characteristics of fraud inherent in every fraudulent act

B. Indicators: Ability in the Detection Stage

1. The auditee's internal control structure is the starting point of the fraud detection I do

2. Understanding the philosophy and operating style of the employees in the auditee environment is one of the routine things I do in every audit assignment

3. A search for an auditee's history of fraud is an activity missed in an audit assignment

4. Besides the types of fraud, I am also able to easily identify parties who can cause fraud.

5. Identifying the factors that cause fraud is the basis for me to understand the obstacles in the identifications of fraudulent acts

6. I include the steps of identifying indications of fraud in the audit program

7. I communicate the results of the fraud identification and provide recommendations to the auditee

Sources: Hartan dan Waluyo (2016)

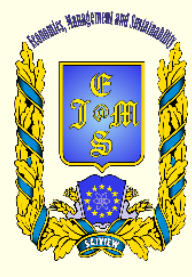

(C) 2016-2021, Economics, Management and Sustainability. All rights reserved.

This open access article is distributed under a Creative Commons Attribution (CC-BY) 4.0 license.

You are free to:

Share - copy and redistribute the material in any medium or format Adapt - remix, transform, and build upon the material for any purpose, even commercially.

The licensor cannot revoke these freedoms as long as you follow the license terms.

Under the following terms:

Attribution - You must give appropriate credit, provide a link to the license, and indicate if changes were made.

You may do so in any reasonable manner, but not in any way that suggests the licensor endorses you or your use.

No additional restrictions

You may not apply legal terms or technological measures that legally restrict others from doing anything the license permits.

Economics, Management and Sustainability (ISSN: 2520-6303) is published by Scientific Publishing House "CSR", Poland, EU and Scientific Publishing House "SciView", Poland

Publishing with JEMS ensures:

- Immediate, universal access to your article on publication

- High visibility and discoverability via the JEMS website

- Rapid publication

- Guaranteed legacy preservation of your article

- Discounts and waivers for authors in developing regions

Submit your manuscript to a JEMS at http://jems.sciview.net or submit.jems@sciview.net

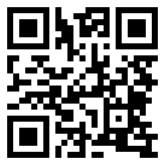

